\title{
Establishment on Evaluation Index System for Urban Logistics Center Location Scheme
}

\author{
Jianhua Chen \\ Hunan Vocational College of Modern Logistics, Changsha, 410131, China \\ 172471928@QQ.com
}

Keywords: urban logistics center; location decision; location principles; evaluation index system; structure model

\begin{abstract}
Based on a scientific and reasonable index system, we scientifically evaluate the location decision of urban logistics centers, and build logistics centers in the best position of cities. It plays an important role in optimizing transportation routes, reducing logistics costs, improving operational efficiency and promoting urban development. Guided by the theory of location selection of urban logistics center, this paper expounds the function of urban logistics center, points out the location principle of urban logistics center, constructs the structure model of evaluation index system, and briefly describes the evaluation index system. The final evaluation index system is composed of 6 first level indicators, including infrastructure, economic factors, social factors, natural environment, logistics costs and business environment, and 4 two level indicators under each level.
\end{abstract}

\section{Introduction}

The logistics center is the infrastructure of the logistics system. It accepts and processes the ordering information of downstream users, centrally stores and processes the large quantities of goods on the upstream suppliers, and transplants the facilities and agencies to the downstream. According to the size of the regional scope of logistics service, the logistics center can be divided into three types: urban logistics center, regional logistics center and international logistics center. The urban logistics center takes a city as the main service object, starts from the whole city's demand for logistics services, and builds on the basis of the city's own characteristics to serve the urban economic and social development. Urban logistics center location is a complicated system engineering, due to the construction of urban logistics center investment, involving many factors, long service life, high risk, location is reasonable or not directly affect the social logistics system, smooth economic and operational efficiency, and have an important influence on the city planning, traffic and city environment etc..

The index system is an organism consisting of several interrelated statistical indicators. Making scientific, systematic and comprehensive index system is the basic work of system evaluation. It is one-sided and subjective to evaluate the location of urban logistics center by using single index or several indexes. Only by scientific and reasonable index system can we get the result of scientific and fair evaluation. In the process of index system construction, we must first follow the general principles of index system construction, and pay attention to the necessity of elements in index system. In the absence of comprehensiveness, we should minimize the number of indicators in the system and pay attention to the function of index system. Based on a scientific and reasonable index system, we scientifically evaluate the location decision of urban logistics centers, and build logistics centers in the best position of cities. It plays an important role in optimizing transportation routes, reducing logistics costs, improving operational efficiency and promoting urban development.

\section{Roles of Urban Logistics Center}

The role of the urban logistics center is concentrated on the following four points:

(1) The city is the goods distribution center and processing center, logistics and infrastructure 
facilities are complete, the circulation of human capital of high consumption, concentrated and high demand, transportation and information developed, the asymmetry in the city and the surrounding area, in the city of asymmetric structure plays a "heart" or "growth pole", with the core of other regional hub will "polarization" into a commodity circulation whole, regional economic radiation of city logistics center belongs to the region of polarization of the French economist "boudeville proposed ". The center of urban flow will become the core of the growth point of logistics industry. It optimizes the structure of logistics, promotes and improves the market system, provides more employment opportunities and improves the economic level of cities.

(2) The principle of service area division of urban logistics centers, according to "economic area" instead of "administrative area", although there may be some coincidence and agreement among the economic and administrative regions, but totally different two concepts. According to the regional economic development center of logistics, to adapt to the development of productive forces, reflects the development of natural resources, economic development and distribution conditions, economic structure and regional structure, labor quality and skills, market level and other aspects, but also reflects the logistics center of the integrity and openness. It is conducive to the formation and improvement of the national logistics system, fully considering the types of the logistics center, the radii of radiation, especially the factors of traffic.

(3) The urban logistics center drives the demand of the surrounding areas. The construction of the urban logistics center has streamlined the transportation line, integrated the cargo station, the freight yard and the related facilities in the center of the city. At the same time, with the deepening of urbanization and the expansion of urban area, the logistics station should move to the surrounding city by the demand of urban development. Therefore, logistics centers built around the city provide new development space for the relatively undeveloped areas, and create new possibilities for urban layout optimization. At the same time, the central construction needs to invest a lot of manpower and material resources to stimulate the needs of the surrounding areas, while increasing the employment of farmers in the surrounding areas, so as to drive the development of the surrounding economy.

(4) The leading logistics enterprises promote the development of the industry. The local government and the industry association lead the industry to carry out the meeting of entrepreneurs in the industry to form the related organizations to promote the development of the industry. We should focus on training the leading enterprises in the existing logistics field, adjust the management mode, introduce skilled personnel, urge other enterprises in the industry to carry out technological reform, and accelerate the competitive advantage of the industry. Enterprises are encouraged to form integrated logistics services businesses including transportation, warehousing, distribution, packaging, freight forwarding and multimodal transport through joint participation and joint ventures. At the same time, for other strong industry benchmarking logistics enterprises, we need to guide and encourage them to enter the logistics park, form a competitive situation and promote the healthy development of the market.

\section{Location Principles of Urban Logistics Center}

The location of the urban logistics center follows the following principles [1,2]:

(1) Systematic principle. The construction of urban logistics center is a huge engineering project. After completion, the layout is not easy to change. There are many links and complex structures in planning and design. Therefore, systematic analysis is needed to ensure the balance of all links. The need for logistics center planning and design work of internal flow of goods route to carry out scientific analysis, ensure the rationality, but also to ensure the scientific external traffic organization structure, the design scheme and the site condition, funding, equipment placement and operation will be integrity of the logistics center location influence. Therefore, in order to ensure the location of the logistics center to meet the requirements, it is necessary to adhere to the principle of systematic nature.

(2) The principle of coordination. The national logistics network is a large system. The location of urban logistics centers can not be divorced from the whole national logistics department. The 
facilities and equipment of urban logistics centers should be coordinated with geographical distribution, logistics operation productivity and technology level. The construction of urban logistics centers should be coordinated with the general layout planning of the city. The analysis of the external radiation direction, the industrial agglomeration area and the residents gathering area of the urban logistics will make the layout of the logistics center suit with it. At the same time, the social effect is considered, including the treatment of garbage and the impact on the ecological environment after the operation of the city logistics center.

(3) The principle of value. With the gradual deepening of socialist marketization and more and more intense competition, the service requirements for the logistics industry are also increased. On the one hand, logistics enterprises should consider logistics cost control rationally, and on the other hand, check the service standard of city logistics center. The construction of city logistics center requires a lot of manpower and resources, the city logistics center location to the feasibility study, put forward a design scheme for comparison, in the details perfect, ensure the logistics center construction has the best economic and social benefits.

(4) Strategic principles. The strategic problem will bring great influence on enterprise management, and it is also a problem in the strategic level of enterprise management. It should be paid attention to by the managers. The early judgment of the strategic problem of the enterprise is an important part of the strategic management of the enterprise, and the judgment and grasp of the strategic problem is also an important embodiment of the quality of the business. The location of the city logistics center should have a strategic vision, one should consider the overall situation, and the two is to consider the long-term. It should obey the overall situation, to the immediate interests to long-term interests, it is necessary to consider the actual needs of the present, but also consider the day after the development.

\section{Structure Model of Evaluation Index System}

The general method of building index system is to sort out and summarize the collected data, and then measure it based on scale. We should not only use logical reasoning method, but also analyze and evaluate the subjective and objective factors based on facts. The establishment of evaluation index system should decompose the actual problems into several factors, and divide them into several groups according to their attributes. Hierarchical structure can generally be divided into the highest level, the middle level and the lowest level. The highest level, also known as the target layer, represents the overall goal of the system. The middle layer is also known as the rule level, which represents the intermediate link to achieve the total goal. According to the size and complexity of the problem, it can be multi-storey. At the bottom, it is also called the plan level, which is expressed as the measures, decisions or plans to achieve the goal. Referring to the relevant literature [3,5], the structure model of the evaluation index system of the urban logistics center location decision is constructed as shown in Fig. 1.

\section{Brief Description of Evaluation Index System}

A brief description of the indicators contained in the evaluation index system model shown in Fig. 1 is as follows:

(1)Infrastructure [6], including four indicators: Road traffic, city logistics center must have good traffic conditions, the best near the transportation hub layout, there are more than two modes of transport connection; Peripheral situation, the logistics center is the key units of prevention of fire, the fire should not be located in the vicinity of easy dissemination industrial facilities, it is not choose the nearby residential areas; Communal facilities requires public facilities such as roads and communications to be equipped with sufficient power, water, heat and gas. Waste disposal has functions of waste burying, garbage burning, garbage stacking, purification and processing.

(2) Economic factors, including four indicators: Gross domestic product, the core indicators of national economic accounting, refers to the city of all resident units of production in a certain period of all final goods and services in the market value; Gross industrial product, the total industrial 
production in the currencies of the industrial enterprises in the reporting period, is the added value of industrial enterprises in the production process; Household consumption level, residents in the consumption process of physical products and services, to meet the needs of people's survival, development and enjoyment needs; Total volume of imports and exports is used to observe the total scale of a city's foreign trade.

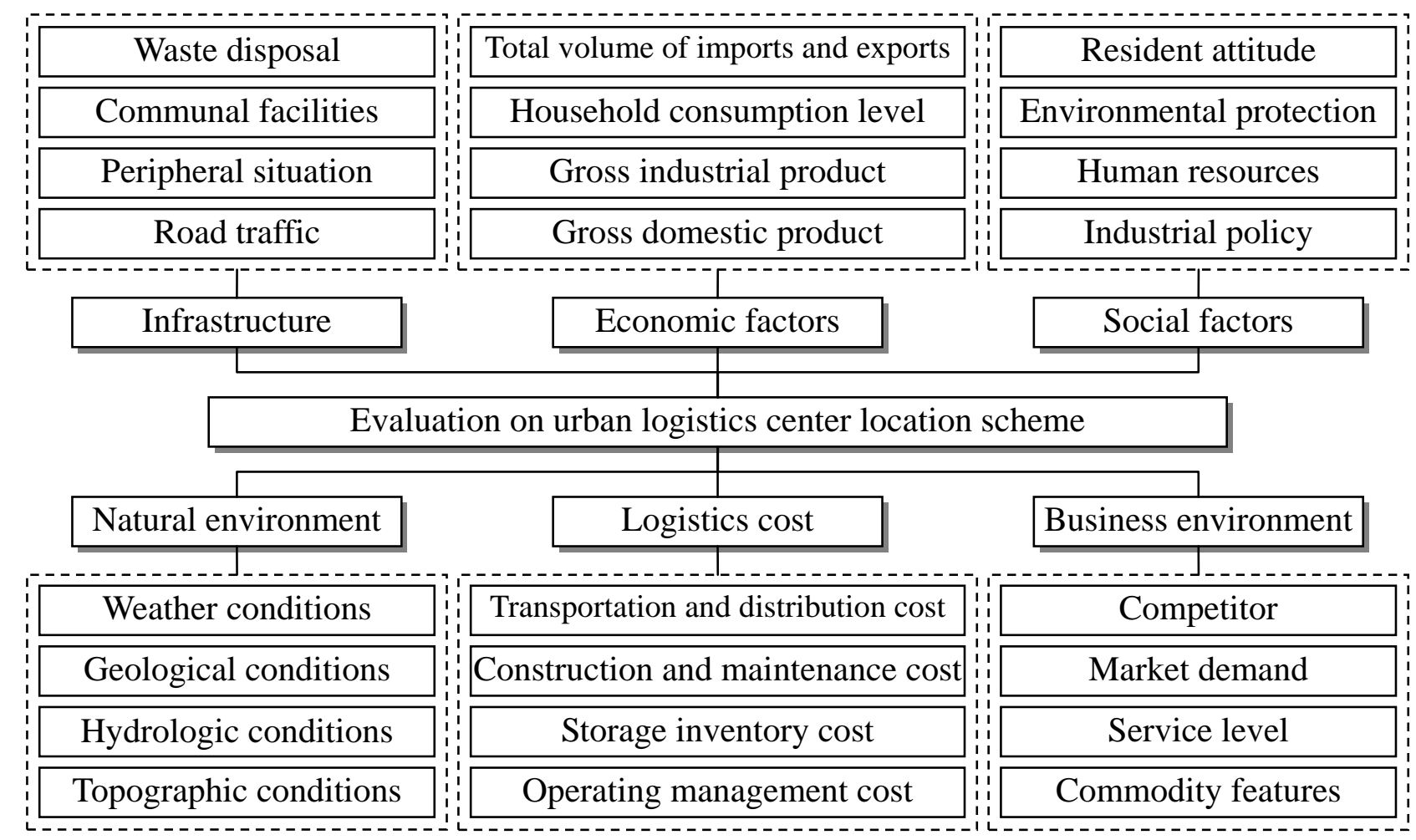

Fig. 1. Structure model on evaluation index system of urban logistics center location scheme

(3) Social factors, including four indicators: Industrial policy, a programmatic document for the development of the logistics industry, the logistics industry development direction and clear the main policies and measures to guide and promote the healthy development of the logistics industry; Human resources, China's logistics talent supply and demand imbalance structure, logistics personnel are included in the shortage of talent the logistics center location, must consider human resources; Environmental protection, the planning of logistics center must pay full attention to the issues of environmental protection and sustainable development of the society; Resident attitude, the attitude of the residents has important influence on the construction of logistics center, the residents support is to improve the construction efficiency and reduce the construction cost of the important factors.

(4) Natural environment, including four indicators: Weather conditions, the need to consider the factors of temperature, wind, precipitation, frost free period and frozen soil depth; Geological conditions, logistics center is the commodity of the build-up, some large bulk building materials piled up will cause great pressure on the ground, the higher bearing capacity of soil; Hydrologic conditions, seriously study the hydrological data, the underground water level is not too high, floodplain, waterlogging area, river and flood, so dry area is absolutely forbidden; Topographic conditions, the logistics center should be the terrain, flat terrain, with appropriate area and shape, in a complete flat terrain is ideal.

(5) Logistics cost [7], according to the cost item division, logistics cost is composed of logistics function cost and inventory related cost. Among them, the logistics function cost includes the packaging cost, transportation cost, warehousing cost, loading and unloading transportation cost, circulation processing cost, logistics information cost and logistics management cost that happen during the logistics activities. Inventory related costs include the cost of capital occupation, inventory costs, insurance and tax costs related to inventory in the course of logistics activities. In 
this paper, the logistics cost is summarized as four indicators: Transportation and distribution cost, Construction and maintenance cost, Storage inventory cost, and inventory.

(6) Business environment, Competitor, if competitors are strong, they should not build logistics centers; Market demand, under the current economic environment and market conditions, the market demand of logistics demand is huge, and the social logistics industry has great development space. Service level, to achieve on-time delivery is an important indicator of the level of service to the modern logistics in the process of logistics center location, should ensure that customers can put forward the logistics demand at any time to the logistics center, can be quickly satisfied with the service; Commodity features, the logistics center belongs to different types of products, the best layout in different respectively. Regional.

\section{Conclusion}

The city logistics center is a comprehensive, regionalism and mass physical displacement location. It occupies a pivotal position in the logistics system. The upstream is the supply center, and the downstream is the supply point or demand point. It plays a connecting role. The reasonable logistics center location decision can effectively save the cost, promote the coordination of production and consumption, and ensure the balanced development of the logistics system. In recent years, the urban scale of our country has expanded rapidly, the number of urban population is increasing rapidly. The new situation of rapid urbanization has brought about the rapid growth of logistics demand. There is an urgent need to establish efficient urban logistics centers that meet the needs of rapid urban development, and provide high quality logistics services for urban residents' clothing, food and shelter and urban development. The location of logistics center is generally divided into three steps: the analysis and prediction of logistics demand, the location decision and location model establishment, and the evaluation of location results. The research content of this paper is used as the intermediate step of site selection. When it is applied, the evaluation index system should be determined flexibly, and the weight can be calculated by appropriate methods. Considering various factors, it can objectively reflect the actual situation and ensure the scientificalness of site selection.

\section{References}

[1] G. Q. Tan, "Analysis and Research on the planning and design of modern logistics center," Basic Construction, vol. 26, no. 13, pp. 101-102, 2017.

[2] Shanghai Jiahe Transport Co., Ltd., "The principle and influence factors of the location of logistics center," http://www.jhdalian.com/news/shddh.htm, 2017-12-20.

[3] M. Wang, H. J. Lan, "Urban logistics performance and its evaluation index system," Journal of Beijing Jiaotong University (Social Sciences Edition), vol. 14, no. 4, pp. 107-113, 2015.

[4] Y. R. Li, Q. N. Zhang, "Evaluation Methods of Logistics Center Location Planning Schemes," Journal of Highway and Transportation Research and Development, vol. 27, no. 2, pp. 143-146, 2010.

[5] Baidu Wenku, "Location principle of distribution center," https://wenku.baidu.com/view/7ad97aac998fcc22bdd10d44.html, 2017-11-19.

[6] Q. Huang, "A comparative study of logistics center location based on AHP fuzzy comprehensive evaluation method," Co-Operative Economy \& Science, vol. 33, no. 15, pp. 31-33, 2017.

[7] L. Y. Hou, J. Q. Yin, "Study on Evaluation Indexes in Designing Logistics Centers," Logistics Technology, vol. 35, no. 9, pp. 51-52, 2015. 